\title{
Análise dos Fatores Influenciadores do Empreendedorismo Ambulante no Setor Alimentício na Cidade de Juazeiro do Norte-CE
}

\author{
Italo Juan Fernandes Azevedo ${ }^{1}$; Márcia Maria Leite ${ }^{2}$
}

Resumo: A prática do empreendedorismo mostra-se cada vez mais frequente no Brasil, sendo uma ótima oportunidade para quem deseja ter o próprio negócio. O presente artigo tem como objetivo identificar os fatores influenciadores que levam indivíduos a torna-se empreenderes ambulantes no setor alimentício na cidade de Juazeiro do Norte-CE. Trata-se de uma pesquisa com natureza descritiva, exploratória e de cunho quantitativo com fundamentação bibliográfica. A pesquisa foi realizada na cidade de Juazeiro do Norte-CE. Na realização da pesquisa foram entrevistados 35 empreendedores ambulantes que estavam localizados ao lado de uma instituição de ensino superior, hospitais e praças públicas da cidade referida. A entrevista contou com 13 perguntas objetivas e subjetivas. Como resultado identificou que o desemprego, desejo pessoal, melhorias da condição financeira, liberdade de tempo e ser útil para a sociedade, são necessidades que motivam o empreendedorismo na cidade em estudo.

Palavras-Chave: Empreendedorismo. Vendedores Ambulantes. Fatores de Motivação.

\section{Analysis of the Influencing Factors of Ambulatory Entrepreneurship in the Food Sector in the City of Juazeiro do Norte in Ceará State}

\begin{abstract}
The practice of the entrepreneurship is shown more and more frequent in Brazil, being the great opportunity for who wants to have the own business. The present article has at objective identifies the factors influencers that you/they take individuals it turns her be undertaken traveling in the nutritious section in the city of Juazeiro of the North-CE. It is treated of the research with nature descriptive, exploratory and of quantitative stamp with bibliographical grounds. The research was accomplished in the city of Juazeiro of the North-CE. In the accomplishment of the research 35 were interviewed enterprising traveling that were located beside the higher education institution, hospitals and public squares of the referred city. The interview counted with 13 questions lenses and subjective. At result identified that the unemployment, personal desire, improvements of the financial condition, freedom of time and useful being for the society, they are needs that motivate the entrepreneurship in the city in study.
\end{abstract}

Keywords: Entrepreneurship. Street vendors. Motivation Factors.

\section{Introdução}

O empreendedorismo é a capacidade de gerar valor para algum produto/serviço que pode ou não ser novo e único no mercado, além de ser o processo dinâmico de criar riqueza através da mudança de

\footnotetext{
${ }^{1}$ Graduando em administração, Centro Universitário Doutor Leão Sampaio, Juazeiro do Norte, Ceará, italojuanfa@gmail.com

${ }^{2}$ Especialização em gestão estratégica de pessoas, Centro Universitário Doutor Leão Sampaio, Juazeiro do Norte, Ceará, marcialeite@leaosampaio.edu.br
}

840 Id on Line Rev. Mult. Psic. V.12, N. 42, p. 840-861, 2018 - ISSN 1981-1179 
comportamento nos negócios, onde o empreendedor assume todas as responsabilidades em termo de comprometimento com metas e objetivos Mendes (2017).

De acordo com a pesquisa publicada pela Global Entrepreneurship Monitor GEM, a Taxa Total de Empreendedores (TTE) brasileiros no ano de 2016 apresentou valor de 36,0 \%, número inferior à observada em 2015 (39,3\%). Porem, a Taxa de Empreendedorismo Inicial (TEA), composta por empreendedores nascentes e novos, alcançou o valor de 19,6\%, também inferior a 2015 (21,0\%). Portanto, a cada 100 brasileiros, aproximadamente 20 estavam envolvidos com atividades empreendedoras em estágio inicial em 2016 (GEM, 2016).

Em virtude de um cenário de crise e grandes mudanças econômicas, políticas e éticas que vive o país, como o aumento do desemprego e outras incertezas, elevou o mercado para um patamar mais competitivo e desafiador, preocupando a população em geral (RIGON, 2016). Diante dessa perspectiva, questiona-se: O que motiva indivíduos montarem negócios em tempo de crise na cidade de Juazeiro do Norte-CE?

Para compreender esta problemática, surgi algumas hipóteses como fatores de causa, exemplo o desejo pessoal de reconhecimento ou prestígio, devido o aumento da taxa de desemprego no país, melhorar a condição financeira, desejo de prestar um serviço que realmente seja útil e traga benefícios para as pessoas e ter mais liberdade de tempo.

O objetivo geral deste estudo é identificar os fatores influenciadores que levam indivíduos a torna-se empreenderes ambulantes no setor alimentício na cidade de Juazeiro do Norte-CE. Quanto aos objetivos específicos é compreender a fundamentação teórica do empreendedorismo; estudar as características do perfil do empreendedor; analisar fatores motivacionais dos ambulantes no setor de alimentos na cidade de Juazeiro do Norte-CE e apresentar esse estudo como fonte de conhecimento para a sociedade, pesquisadores e futuros empreendedores.

O estudo pauteia conhecimentos teóricos e práticos, proporcionando uma visão de habilidades, oportunidades e competências no decorrer da graduação e desenvolvimento profissional. O conhecimento adquirido com a pesquisa pode dar suporte para a sociedade e pessoas que pretendem empreender no ramo alimentício na cidade de Juazeiro do Norte-CE.

\section{Conceituando Empreendedorismo}

As evidências reportadas pela literatura acerca da natureza complexa e motivos do empreendedorismo transcendem o binômio "oportunidade" ou "necessidade". O empreendedorismo 
vem ganhando força, onde cada vez mais só aumenta o número de pessoas que tem alguma ideia ou desejo de transforma-la em oportunidades, se tornando assim um empreendedor com uma nova visão de negócios e assumindo riscos calculados, quebrando velhos paradigmas e renovando alguns conceitos econômicos para gerar riqueza à sociedade (DORNELAS, 2016).

Segundo Dornelas (2016) destaca que o empreendedorismo no Brasil surgiu na década de 1990 com a criação de entidades como Serviço Brasileiro de Apoio ás Micro e Pequenas Empresas SEBRAE e Sociedade Brasileira para Exportação de Software SOFTEX, as quais possuem o intuito de agregar suporte para quem pretende iniciar uma empresa, bem como consultorias para resolver problemas pontuais do negócio e capacitação de gestão.

Conforme Mendes (2017) o empreendedorismo é a capacidade de gerar valor para algum produto ou serviço que pode ou não ser novo ou único no mercado, além de ser o processo dinâmico de criar riqueza através da mudança de comportamento nos negócios, onde o empreendedor assume todas as responsabilidades em termo de comprometimento com metas e objetivos.

O gráfico 01 apresenta a evolução histórica das taxas de empreendedores nascentes e novos no Brasil, os quais estão inseridos na classificação de empreendedores iniciais. Ao longo do período de análise percebeu-se uma constante variação da taxa de empreendedores nascentes, oscilando entre 3\% e 7\%. Para o ano de 2016 a referida taxa apresentou valor de 6,2\%, valor menor ao encontrado em 2015 $(6,7 \%)(\mathrm{GEM}, 2016)$.

Gráfico 01: Taxas de Empreendedorismo Novo e Nascente no Brasil em 2016.

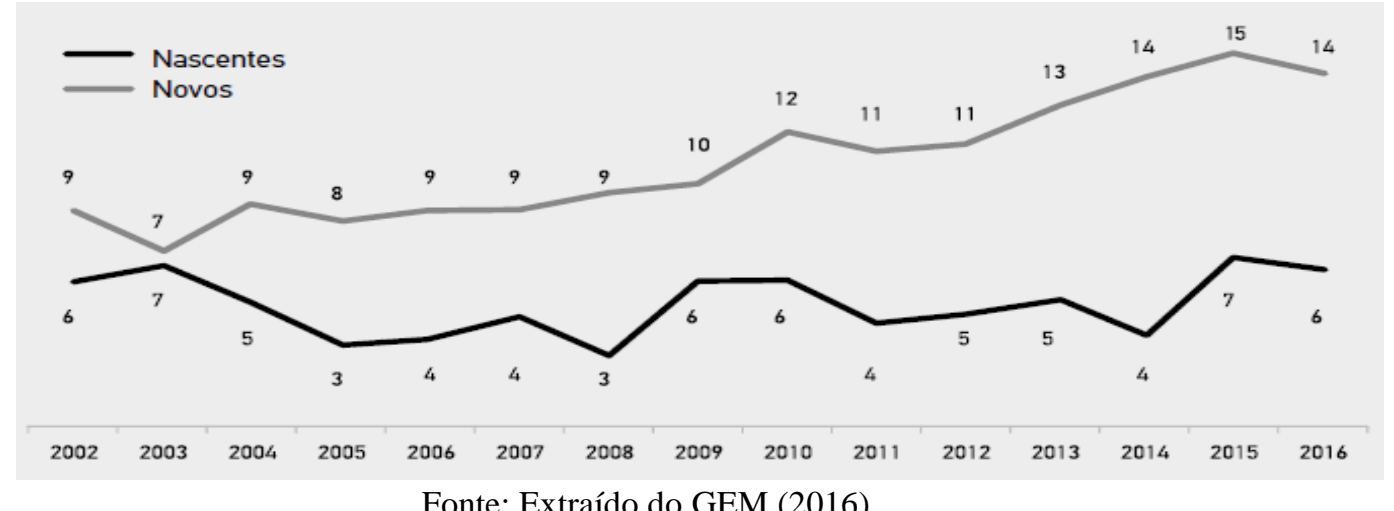

Os dados revelam que em 2016 houve uma redução da respectiva taxa, retornado ao patamar de 2014, cujo valor foi de $14 \%$. Sob este aspecto, pode-se inferir que a crise econômica impactou diretamente ambas as taxas, resultando em desaquecimento da atividade empreendedora total no médio 
prazo, primordialmente em função da ausência de empreendedores iniciais que alcancem o estágio de empreendedor estabelecido. Observa-se, ainda que há no caso dos empreendedores nascentes maior sensibilidade em relação à atividade econômica do país do que para os empreendedores novos. (GEM, 2016).

Em suma, apesar da conjuntura econômica desfavorável dos anos recentes a mentalidade empreendedora está ligada a diversos fatores contribuem para o surgimento de uma cultura empreendedora e para a criação de novos negócios, envolvendo itens mais amplos como economia, legislação, questões sociodemográficas até fatores familiares e pessoais.

Figura 01: Contexto Empreendedor.

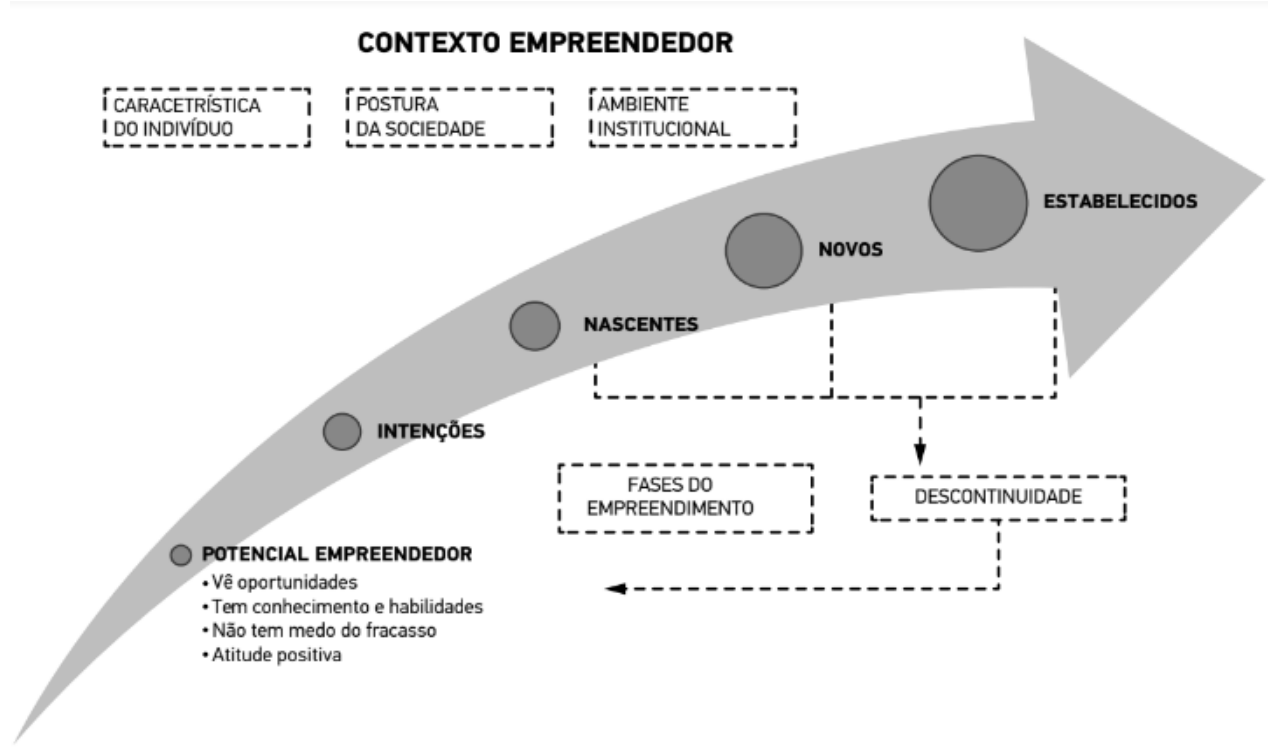

Fonte: Extraído do GEM (2016).

Dentre esse contexto empreendedor estão as características e o novo perfil socioeconômico do empreendedor brasileiro. Dados da pesquisa GEM (2016) mostra que dentre esse perfil estão à faixa etária, renda, escolaridade, estado civil e cor dos indivíduos. A pesquisa apresentou uma supremacia feminina entre os empreendedores iniciais, com $51,5 \%$, enquanto a masculina foi de $48,5 \%$.

A igualdade entre homens e mulheres à frente de novos negócios não se mantém quando é analisada a participação por gênero nos empreendimentos estabelecidos mais de 3,5 anos, $57,3 \%$ são homens, enquanto 42,7\% são mulheres, representado, uma diferença de 14,6\% entre os gêneros. 
Tabela 01: Taxas Específicas1 de Empreendedorismo Inicial (TEA), Segundo Nível de Escolaridade.

\begin{tabular}{|c|r|r|r|r|r|}
\hline Paises & $\begin{array}{c}\text { Alguma } \\
\text { educaçäo }\end{array}$ & $\begin{array}{c}\text { Secundário } \\
\text { completo }\end{array}$ & $\begin{array}{c}\text { Pós- } \\
\text {-secundário }\end{array}$ & $\begin{array}{r}\text { Experiência } \\
\text { pós-graduaçäo }\end{array}$ & \multicolumn{2}{|c|}{ TEA } \\
\hline Brasil & 19,5 & 20,5 & 14,4 & 22,9 & 19,6 \\
\hline
\end{tabular}

Fonte: Extraído do GEM (2016).

A análise da TEA segundo faixas etárias mostra que no Brasil esta variou entre 15\% para a faixa etária entre 55 e 64 anos, a 22,9\% na faixa etária dos 25 aos 34 anos. Quanto à escolaridade dos empreendedores foi revelada na pesquisa que a maioria possui "experiência pós-graduação", para indivíduos com mestrado completo e doutorado incompleto ou completo com $(22,9 \%)$. Isto não significa que a maioria dos novos empreendimentos é constituída por mestres e doutores, pois de acordo com o OPNAD (2014) apenas $13,1 \%$ da população brasileira acima de 25 anos tem curso superior completo.

Vale destacar que a participação em novos empreendimentos é equilibrada nas diversas faixas de escolaridade, onde respondentes com "alguma educação" apresentam TEA de 19,5\%, indivíduos com "secundário completo" possuem taxa de $20,5 \%$ e aqueles com "pós-secundário" tem menor TEA $(14,4 \%)$. Este dado revela a necessidade de incluir na educação básica (fundamental e médio) discussões e conteúdo.

Quanto à taxa específica para empreendimentos estabelecidos (TEE), Indivíduos neste indicador há predominância de TEE para indivíduos da maior faixa de renda $(22,1 \%)$, seguido de empreendedores da faixa central $(19,1 \%)$ e menor expressividade para indivíduos da faixa de renda inferior $(12,1 \%)$. Esta situação pode ser derivada da dificuldade de financiamento para atividades empreendedoras no Brasil.

\section{Oportunidade Versus Necessidade}

Segundo Lenzi (2009) a oportunidade é uma ideia que está vinculada a um serviço ou produto além da implementação de inovações e melhorias nos processos, produtos ou serviços, satisfazendo as necessidades dos clientes, facilitando o empreendedorismo e a promoção do desenvolvimento econômico na sociedade brasileira.

$\mathrm{Na}$ figura 02 são apresentados fatores de importância para o empreendedor, entre eles pode-se destacar a motivação, habilidade e oportunidades. 
Figura 02: Fatores de Importância para o Empreendedor.

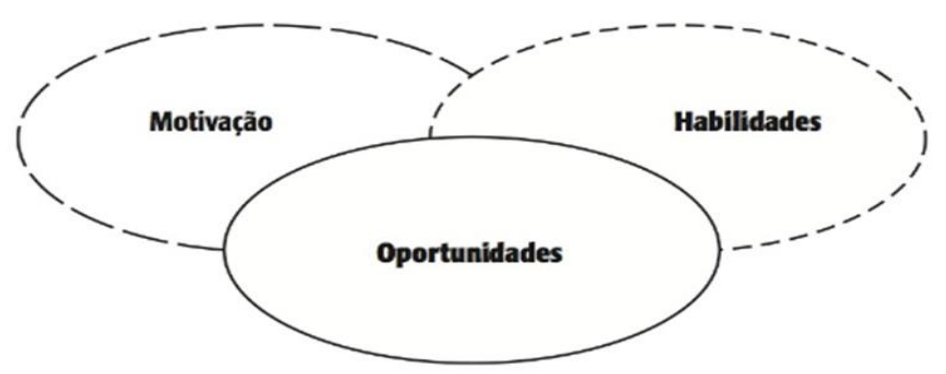

Fonte: Extraído de Julien (2010)

Pode-se observar na figura 02 a existência de três razões pessoais e sociais para empreender e criar um novo negócio, sendo essas razões intimamente ligadas. Destacando as motivações, habilidades e oportunidades, juntas podem ajudar a dirigir e organizar a construção da empresa, garantindo visibilidade e sucesso (JULIEN, 2010).

Como se observa a motivação, habilidades e oportunidades estão intimamente ligadas, mesmo que em certas circunstancia uma dessas competências seja mais importante, com relação à outra, todavia juntas são de fundamental importância para o sucesso da organização e empreendedor (JULIEN, 2010).

De acordo com Maritz (2004) as distinções entre as orientações ao empreendedorismo dependem, fundamentalmente, da motivação do empreendedor. Já o empreendedor por "necessidade" é aquele que nunca havia considerado a abertura de um negócio até que não houvesse outra opção. Para os autores Kautonen e Palmroos (2010), existe outro aspecto de empreendedorismo por "necessidade" que é quando o empregador incentiva desempregados a empreenderem para prestar serviços, estabelecendo assim uma relação de parceria/fornecedor, o que, segundo não deixa de ser uma zona cinzenta entre o emprego e o auto emprego precário.

O empreendedorismo por oportunidade é quando o empreendedor, mesmo com outras possibilidades de renda, prefere criar seu próprio negócio, diferenciando da oportunidade o empreendedorismo por necessidade é quando o empreendedor não tem outra opção de renda melhor, este tipo de empreendimento traz consigo uma urgência no recebimento de lucros e, em muitos casos, alguma precariedade em sua condução, dado a falta de planejamento, o desconhecimento do mercado e as restrições quanto aos investimentos iniciais. O empreendedor por oportunidade normalmente já tem proventos de outras atividades, possui uma maior escolaridade, tem mais tempo, capacitação e recursos para criar e conduzir o negócio (GEM, 2016).

A Global Entrepreneurship Monitor - GEM realizou uma pesquisa no ano de 2016 contemplando 69 países sobre as motivações para o empreendedorismo, partindo da premissa de que 
os indivíduos são impelidos a este por dois motivos antagônicos: "necessidade "ou "oportunidade". Na tabela a seguir 02 são apresentados os percentuais das atividades dos empreendedores nascentes por oportunidade, ou seja, aqueles que possuem empreendimentos que ainda não os remuneraram por mais de três meses, segundo a sua motivação (GEM, 2016).

Tabela 02: Atividades dos Empreendedores Nascentes por Oportunidade.

\begin{tabular}{|c|c|c|c|}
\hline \multicolumn{2}{|l|}{ Oportunidade } & \multicolumn{2}{|l|}{ Necessidade } \\
\hline Atividades (CNAE) & $\%$ & Atividades (CNAE) & $\%$ \\
\hline $\begin{array}{l}\text { Restaurantes e outros estabelecimentos de } \\
\text { serviços de alimentação e bebidas }\end{array}$ & 9,5 & $\begin{array}{l}\text { Restaurantes e outros estabelecimentos de } \\
\text { serviços de alimentação e bebidas }\end{array}$ & 29,3 \\
\hline $\begin{array}{l}\text { Comércio varejista de artigos do vestuário e } \\
\text { acessórios }\end{array}$ & 9,3 & $\begin{array}{l}\text { Serviços de catering, bufê e outros serviços de } \\
\text { comida preparada }\end{array}$ & 9,3 \\
\hline $\begin{array}{l}\text { Manutenção e reparação de veículos } \\
\text { automotores }\end{array}$ & 6,9 & Serviços ambulantes de alimentação & 6,9 \\
\hline $\begin{array}{l}\text { Serviços de catering, bufê e outros serviços de } \\
\text { comida preparada }\end{array}$ & 6,2 & $\begin{array}{l}\text { Comércio varejista de artigos do vestuário e } \\
\text { acessórios }\end{array}$ & 6,8 \\
\hline $\begin{array}{l}\text { Cabeleireiros e outras atividades de } \\
\text { tratamento de beleza }\end{array}$ & 5,6 & & \\
\hline Serviços ambulantes de alimentação & 4,1 & & \\
\hline Serviços especializados para construção & 3,4 & & \\
\hline $\begin{array}{l}\text { Comércio varejista de cosméticos, produtos de } \\
\text { perfumaria e de higiene pessoal }\end{array}$ & 3,3 & & \\
\hline Comércio varejista de bebidas & 2,3 & & \\
\hline Outras atividades & 49,3 & Outras Atividades & 47,7 \\
\hline
\end{tabular}

Fonte: Extraído do GEM (2016).

Por esta motivação, as atividades que se destacaram foram a de "restaurantes e outros estabelecimentos de serviços de alimentação e bebidas" (9,5\%), "comércio varejista de artigos do vestuário e acessórios" (9,3\%) e "manutenção e reparação de veículos automotores" (6,9\%).

Tabela 03: Atividades dos Empreendedores Novos por Necessidade.

\begin{tabular}{|c|c|c|c|}
\hline \multicolumn{2}{|l|}{ Oportunidade } & \multicolumn{2}{|l|}{ Necessidade } \\
\hline Atividades (CNAE) & $\%$ & Atividades (CNAE) & $\%$ \\
\hline $\begin{array}{l}\text { Restaurantes e outros estabelecimentos de } \\
\text { serviços de alimentação e bebidas }\end{array}$ & 10,4 & $\begin{array}{l}\text { Serviços especializados para construção não } \\
\text { especificados }\end{array}$ & 15,6 \\
\hline $\begin{array}{l}\text { Cabeleireiros e outras atividades de } \\
\text { tratamento de beleza }\end{array}$ & 9,2 & Serviços domésticos & 14,9 \\
\hline $\begin{array}{l}\text { Comércio varejista de artigos do vestuário e } \\
\text { acessórios }\end{array}$ & 8,9 & $\begin{array}{l}\text { Cabeleireiros e outras atividades de } \\
\text { tratamento de beleza }\end{array}$ & 9,7 \\
\hline $\begin{array}{l}\text { Serviços de catering, bufê e outros serviços de } \\
\text { comida preparada }\end{array}$ & 7,7 & $\begin{array}{l}\text { Comércio varejista de artigos do vestuário e } \\
\text { acessórios }\end{array}$ & 7,3 \\
\hline $\begin{array}{l}\text { Comércio varejista de cosméticos, produtos de } \\
\text { perfumaria e de higiene pessoal }\end{array}$ & 5,0 & & \\
\hline Serviços domésticos & 4,1 & & \\
\hline Serviços especializados para construção & 3,7 & & \\
\hline Serviços ambulantes de alimentação & 3,0 & & \\
\hline Outras atividades & 48,0 & Outras Atividades & 52,4 \\
\hline
\end{tabular}

Fonte: Extraído do GEM (2016). 
Na tabela 03 o empreendedorismo por necessidade traz consigo uma urgência no recebimento de lucros e, em muitos casos, alguma precariedade em sua condução, dado a falta de planejamento, o desconhecimento do mercado e as restrições quanto aos investimentos iniciais (GEM, 2016). A pesquisa também apresentou que empreendedores de empresas nascentes que criaram seu negócio por necessidade se empenharam em "Restaurantes e outros estabelecimentos de serviços de alimentação e bebidas" (29,3), "Serviços de catering, bufê e outros serviços de comida preparada" (9,3\%) e "Serviços ambulantes de alimentação" (6,9\%).

\section{Fatores Motivacionais}

Os fatores motivacionais que impulsiona o empreendedorismo são necessidade, sendo as razões que motiva por faltas de espaço no mercado formal ou demissão, e oportunidade, tendo os desejos de autonomia, realização financeira, decisão planejada ou missão de vida (DORNELAS, 2014).

De acordo com Oliveira (2014) alguns dos fatores de motivação no empreendedor, principalmente os brasileiros, são o objetivo de montarem o próprio negócio, liberdade financeira, flexibilidade de trabalho, oportunidades dos novos modelos de empreendimentos e independência pessoal.

Baggio e Baggio (2014) apud Robbins (2005) mencionam que a motivação é o processo responsável por dar intensidade, persistência e direção aos esforços das pessoas no alcance de uma meta ou objetivo. O mesmo autor discute ainda que existem fatores que motivam o empreendedor distribuído em três esferas, pessoais, ambientais e sociológicos.

O fator pessoal está relacionado ao desejo de auto realização, insatisfação no trabalho, desejo de ganhar dinheiro e melhorar a condição financeira, iniciativa ardente de mudar de vida ou adquirir nova oportunidade de emprego, mediante a uma situação de desemprego, como exemplo (BAGGIO e BAGGIO, 2014 apud ROBBINS, 2005). No fator ambiental, a motivação perpetua o estudo do ambiente onde se pretende inserir um negócio, estudando as oportunidades e incertezas existentes, compreendendo a possibilidade de investir em um projeto empreendedor; com o fator sociológico, compreende-se a iniciativa de um grupo de pessoas competentes, compartilhando características comuns, influenciar outros grupos, que podem ser formados por familiares, amigos ou colegas, uma vez motivando a abertura de determinado negocio pelo simples fato de entender que as possibilidades para desenvolver são favoráveis (BAGGIO e BAGGIO, 2014 apud ROBBINS, 2005). 


\section{Reconhecimento de Oportunidade}

No universo do empreendedorismo uma oportunidade de negócio pode representar uma possibilidade para o empreendedor atender uma necessidade insatisfeita, ou desejos de uma sociedade ou clientes, o que resulta em vendas e lucros. O reconhecimento de uma oportunidade em geral é consequência do conhecimento e da experiência do empreendedor individual e, onde for pertinente, da empresa empreendedora (HISRICH, 2014). Na figura 03 Hisrich (2014), demonstra o processo de reconhecimento da atenção e das redes empreendedoras.

Figura 03: Reconhecimento de Oportunidade.

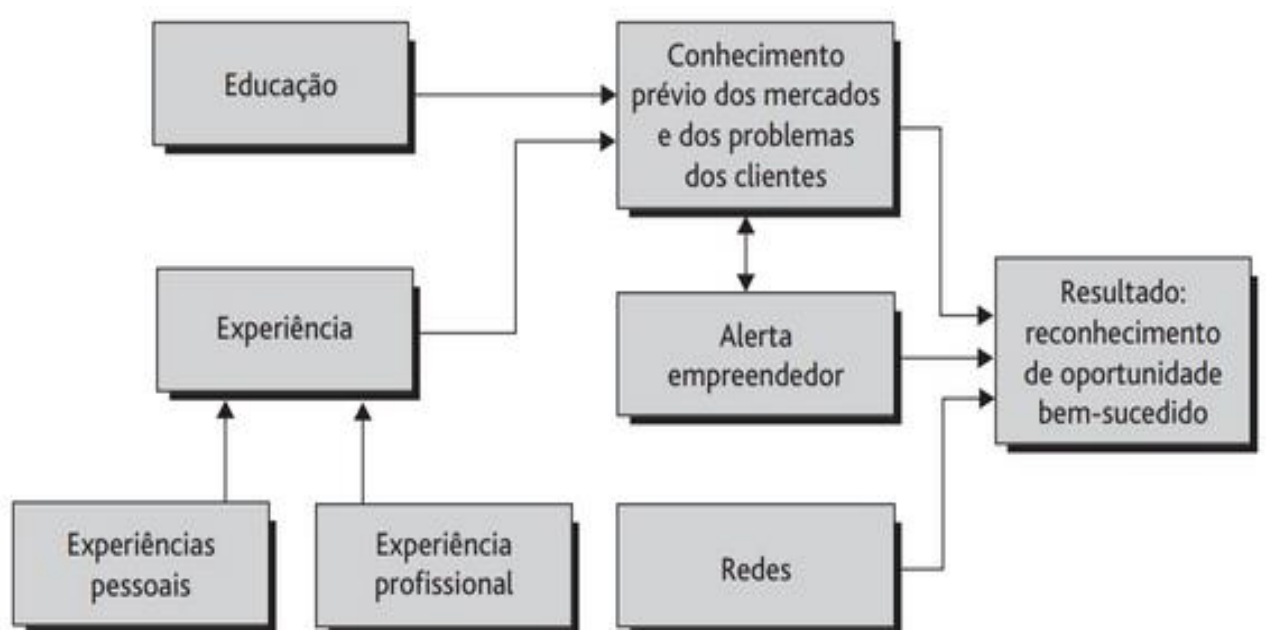

Fonte: Extraído Hisrich (2014)

Observa na figura 03 que o reconhecimento da oportunidade empreendedora surge não apenas na criação de um novo produto, mas através de uma rede que envolve visão, reflexão, cultura, tecnologia e experiências. O tema recorrente dessa história é que as oportunidades empreendedoras representam algo novo.

Segundo Tajra (2014) para identificar e criar suas próprias oportunidades, o empreendedor deve está em constante atenção aos movimentos e mudanças que estão ocorrendo ao redor, sempre se mantendo atualizado, agregando valor aos seus processos e serviços de forma inovadora e obtendo sucesso através do empreendimento.

Com base na A Global Entrepreneurship Monitor - GEM em 2016 período de retração da economia nacional o empreendedorismo continuou a crescer, porém, agora puxado pela sua componente por necessidade. Isto pode significar que o empreendedorismo no Brasil pode estar assumindo um 
comportamento mais independente do nível de atividade econômica, talvez sendo mais fortemente influenciado na última década por outros fatores estruturais que também estão em processo de mudança, tais como: o aumento do nível de escolaridade dos brasileiros e por negócios mais simples e de menor escala de faturamento, como a lei responsável por criar o MEI; ou até mudanças na cultura brasileira, agora, cada vez mais propensa à atividade empreendedora.

Gráfico 02: Taxas de Oportunidade e Necessidade.

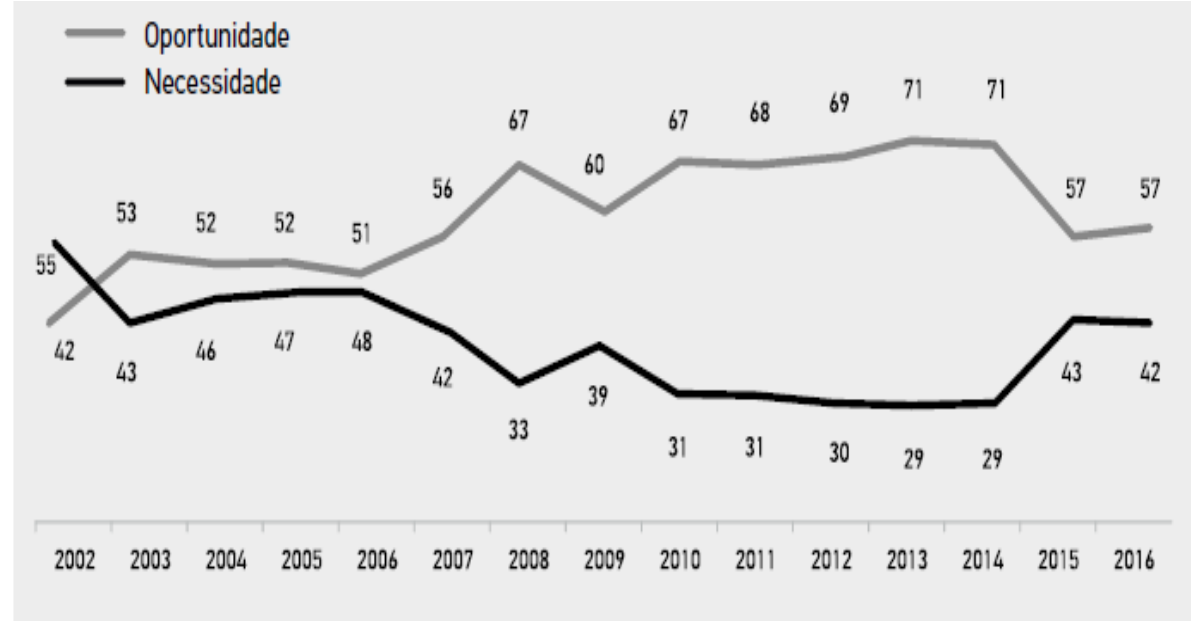

Fonte: Extraído do GEM (2016).

Vale ressaltar que as taxas apresentam correlação negativa, ou seja, à medida que a taxa de empreendedores por necessidade diminui, aumento da taxa de empreendedores por oportunidade e viceversa. No Brasil, o ano de 2016 apresentou uma melhora sutil se comparado a 2015 (56,5\%), com o valor de 57,4\%. Portanto, a cada 100 empreendedores, 57 empreendem por Oportunidade (GEM, 2016).

Concluída a breve apresentação dos conceitos de empreendedorismo e os fatores motivacionais a seguir são reportados os aspectos metodológicos adotados na condução desta pesquisa.

\section{Metodologia}

Esta pesquisa é aplicada quanto à sua natureza descritiva, exploratória e de cunho quantitativo com fundamentação bibliográfica. A amostra consistiu em 35 empreendedores ambulantes que por conveniência e acessibilidade trabalham em lugares públicos próximos à instituição de ensino, praças e hospitais. É importante destacar que a pesquisa obteve uma amostra mínima de participantes em virtude 
de alguns empreendedores terem receios que a finalidade da mesma fosse de concorrentes ou de fiscalização.

A pesquisa foi realizada na cidade de Juazeiro do Norte-CE, onde esta referida cidade, tem a figura do padre Cicero Romão Batista como um marco na construção da religiosidade e cultura. Possui uma distância de $491 \mathrm{~km}$ da capital Fortaleza e soma uma população de 270.383 habitantes, segundo o Instituto Brasileiro de Geografia e Estatística - IBGE (2016).

A estratégia de abordagem foi através de instrumento de coleta de dados o questionário contendo 13 perguntas estruturadas objetivas e subjetivas. No decorrer da entrevista, as intervenções foram minimizadas para que o entrevistado mantivesse autonomia ao falar sua própria linguagem e abordar seus próprios problemas (QUEIROZ, 1991).

A abordagem é quantitativa por se tratar da interpretação de dados estatísticos ao mensurar dados quantificáveis de determinada amostra (MALHEIROS, 2011). A pesquisa é de cunho exploratório, ao proporcionar maiores informações sobre um assunto específico, definir os objetivos, formular as hipóteses e avaliar a possibilidade de desenvolver uma boa pesquisa sobre um determinado assunto, sendo ainda descritiva, visto que todos os fatos observados não são manipulados pelo pesquisador e a coleta de dados descreve todo um evento estudado (ANDRADE, 2010).

A tabulação dos dados aconteceu por intermédio do software Excel Em seguida ocorreu a analise dos resultados confrontando a fundamentação teórica apresentada neste artigo.

\section{Análise e Discussão dos Resultados}

A pesquisa foi realizada na cidade de Juazeiro do Norte-CE, com 35 (trinta e cinco) ambulantes, sendo 21 homens e 14 mulheres no período 18 a 22 de setembro de 2018. A mesma foi realizada através de um questionário contendo 13 perguntas entre elas objetivas e subjetivas. Os dados obtidos foram organizados e distribuídos em gráficos para a análise e discussão dos resultados. 
Gráfico 03: Cruzamento de Gênero e Faixa Etária.

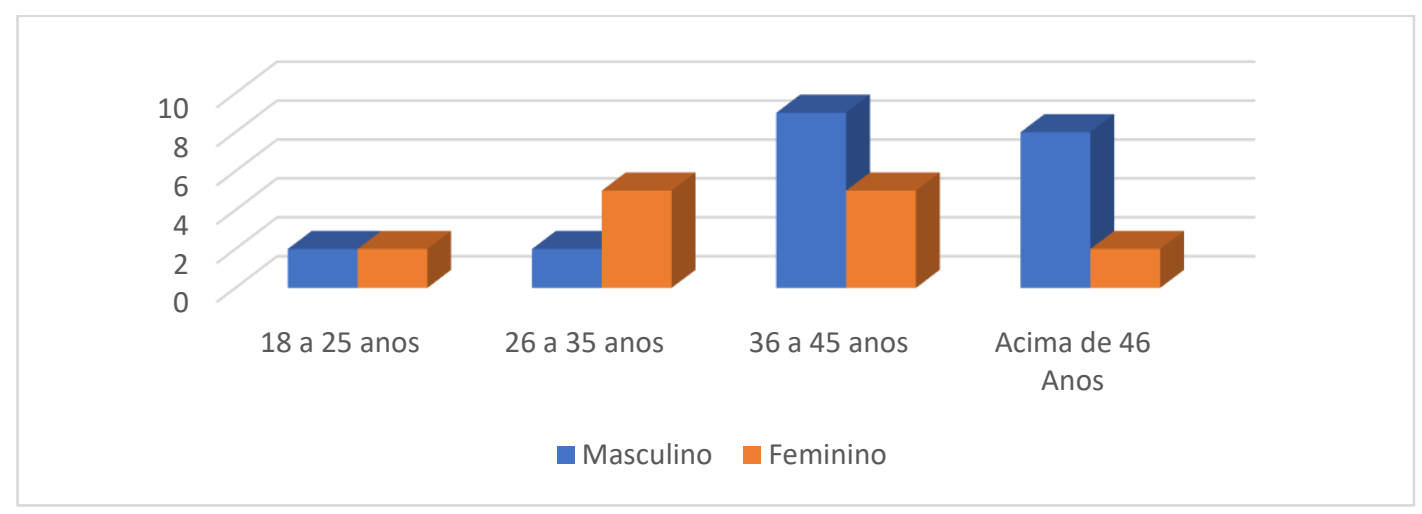

Fonte: Dados da pesquisa 2018.

Os dados do gráfico 03 revelam uma supremacia masculina no desenvolvimento dos negócios pesquisados. Pode-se observar que a faixa etária que mais se destaca é a partir dos 36 anos aos 46.

Este dado reflete a pesquisa realizada em 2016 pela Global Entrepreneurship Monitor - GEM onde revelam que as mulheres brasileiras conseguem criar novos negócios, porém enfrentam mais dificuldades para fazer seus empreendimentos prosperarem. Tal fenômeno pode estar associado às condições relatadas pelas empreendedoras brasileiras como: preconceito de gênero; menor credibilidade pelo fato de o mundo dos negócios ser mais tradicionalmente associado a homens; maior dificuldade de financiamento; e dificuldade para conciliar demandas da família e do empreendimento

Observa-se, ainda que a menor proporção desses empreendedores possua idade entre 18 a 25 anos e que as mulheres de 26 a 35 anos tem mais tendência de empreender com relação aos homens.

Gráfico 04: Cruzamento de Gênero e Escolaridade.

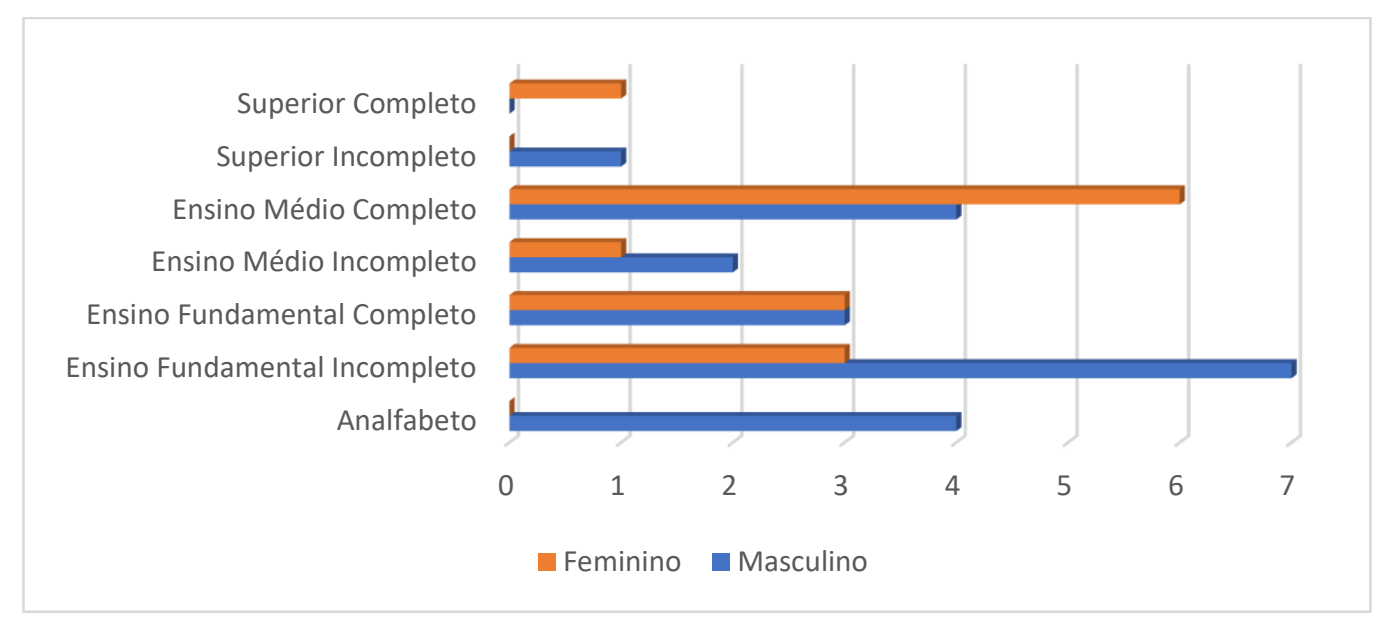

Fonte: Dados da pesquisa 2018. 
O gráfico 04 destina-se a apresentar o nível de escolaridade dos empreendedores aonde esse dado mostra que as mulheres têm mais tendência em buscar novos aprendizados. Percebe-se também que a maior taxa de analfabetismo se encontra no gênero masculino e é possível observar com maior clareza que quanto maior o nível de escolaridade as possibilidades de inserção no mercado de trabalho são maiores afetando a representatividade desta parcela da população no contexto empreendedor.

O interessante é que a pesquisa da GEM (2016) aponta que a maioria dos empreendedores brasileiros possui nível superior, destacando indivíduos com mestrado completo e doutorado incompleto ou completo. Porém o gráfico 04 revela que a maioria dos entrevistados possui ensino médio completo ou incompleto. Pontuando também que as mulheres, em grande número, tem ensino médio completo. No entanto, os homens apresentam ensino médio incompleto. Vale enfatizar que a OPNAD (2014) aponta apenas $13,1 \%$ da população brasileira acima de 25 anos tem curso superior completo, confirmando o resultado expressos no gráfico 04.

Gráfico 05: Formalização.

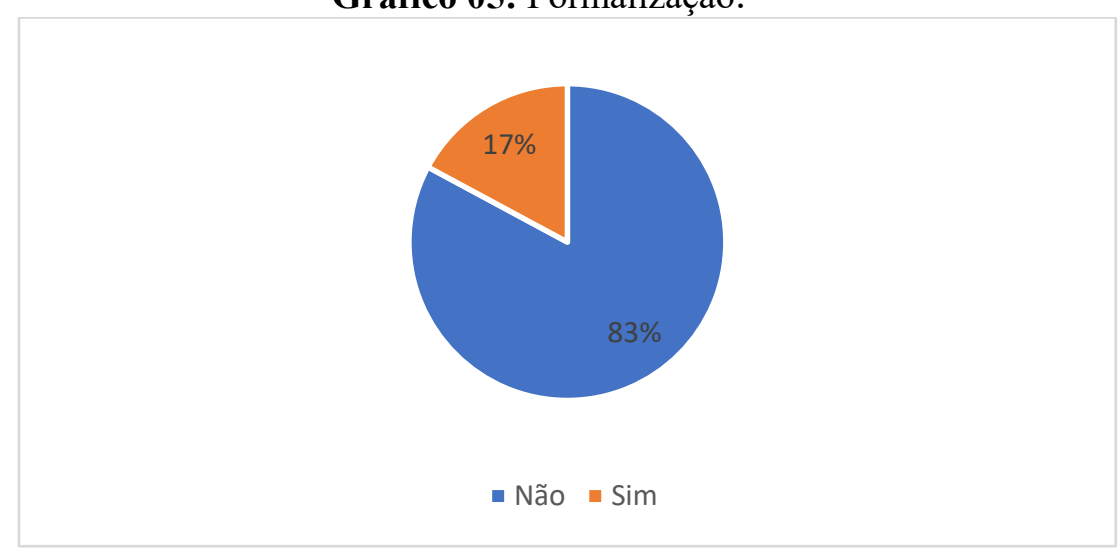

Fonte: Dados da pesquisa 2018.

De acordo com o gráfico 05, o qual representa a formalização dos empreendedores, ao analisar a amostra percebe-se que apenas uma pequena parcela (17\%) dos empreendedores possui CNPJ. Sendo que existem órgãos que dão suporte passo a passo para se torna um Micro Empreendedor Individual MEI onde pode ser feita pela internet e tem custos baixos garantindo assim alguns benefícios para o empreendedor. Conforme a pesquisa realizada pelo Global Entrepreneurship Monitor - GEM em 2016 os fatores que levam os empreendedores a não buscarem ajuda em órgãos de apoio destacam-se, primeiramente a falta de conhecimento ou informações desses serviços $(42,2 \%)$, seguidos pela falta de interesse dos empreendedores $(40,8 \%)$, da falta de necessidade $(21,5 \%)$ e da falta de tempo $(12,2 \%)$. 
Gráfico 06: Quantos Negócios Já Montaram.

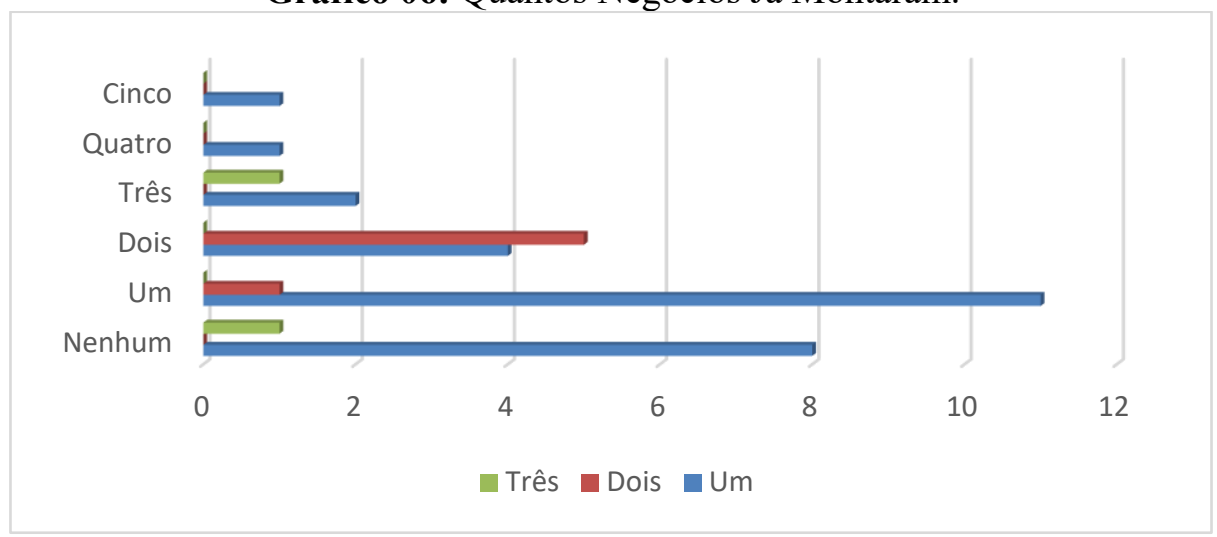

Fonte: Dados da pesquisa 2018.

É perceptível no gráfico 06 que a maioria dos ambulantes já montou pelo menos um tipo de negócio, contendo também uma parcela daqueles que nunca iniciou nenhum tipo de empreendimento. É nítida ainda a existência de expressividade para aqueles que montaram dois negócios, onde se pode julgar o insucesso, visto pelo o ângulo quantitativo de ideias empreendedoras iniciadas, mas não finalizadas, podendo também agregar para os que já iniciaram três, quatro ou cinco empreendimentos e que por alguma razão veio à falência.

Chama atenção o fato de o empreendedor ter montado mais de um tipo de negócio, podendo ser caracterizado como erro e tentativa, quando o indivíduo idealiza uma oportunidade, porém não a concretização de um planejamento. Levando o empreendimento à falência, pela falta de mecanismos para gerenciar a ideia empreendedora.

Gráfico 07: Tempo de Atuação.

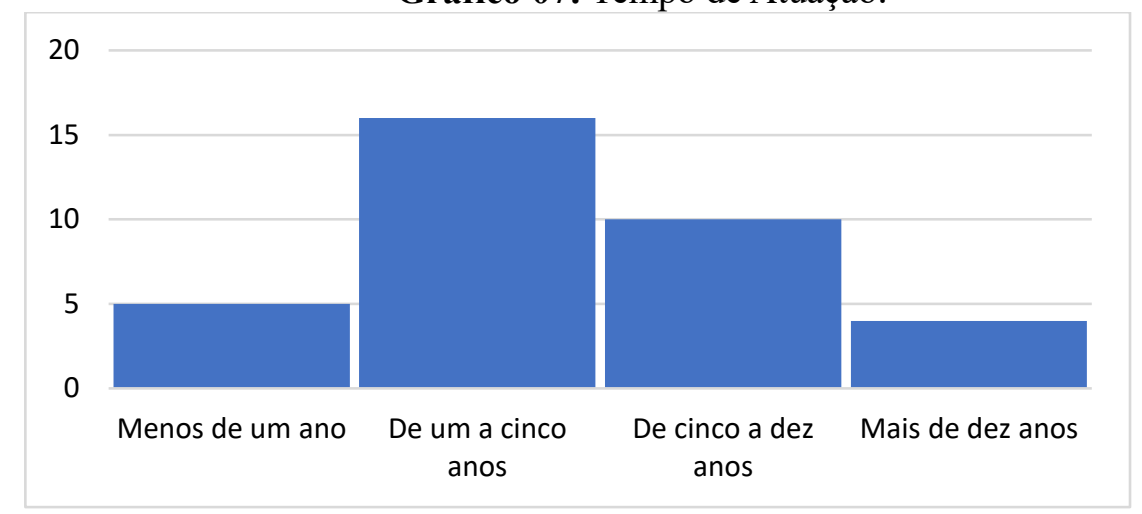

Fonte: Dados da pesquisa 2018. 
O gráfico 07 destina-se há apresentar o tempo em que um empreendedor permanece atuando em determinado negócio. É possível observar com clareza que entre (1 a 5 anos) um a cinco anos tem maior predominância de tempo, seguido por (5 a 10 anos) cinco a dez anos. Pode-se observar que os empreendedores atuam e se dedicam por muito tempo ao seu empreendimento. $\mathrm{O}$ curioso é que a maioria possui mais de ( 1 ano) um ano de funcionamento, levando a questionar-se o motivo de não inovar, buscar diferenciais competitivos ou formas de melhorias no negócio.

Gráfico 08: Fatores que Levou Montar o Próprio Negócio.

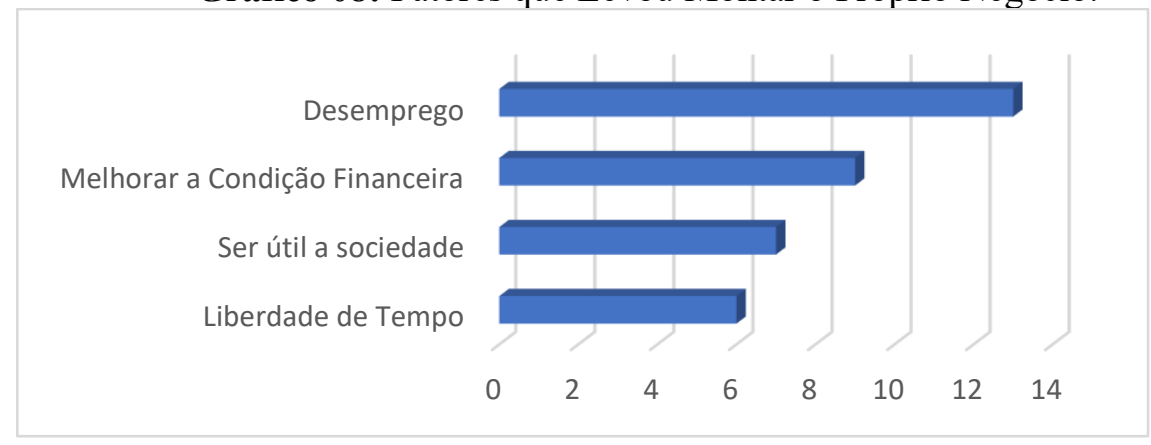

Fonte: Dados da pesquisa 2018.

Dentre esses fatores descritos no gráfico 08, destaca-se um grande índice no fator desemprego, levando as pessoas que não possuem melhores alternativas de emprego a criar seu próprio negócio visando basicamente à subsistência própria e de familiares. Seguida pelo fator melhorar a condição financeira, propondo-se criar um negócio que gere rendimentos e lucratividade. Esse dado mostra que ser útil a sociedade e ter mais liberdade de tempo, são fatores fundamentais para montar o próprio negócio como menciona Robbins (2005).

Estes fatores correspondem às necessidades em querer empreender, ressaltando que a pesquisa realizada pela GEM aponta que a taxa de empreendedores por oportunidade diminuiu e a por necessidade aumentou no Brasil em 2016, considerando o no gráfico 02. 
Gráfico 09: As Vantagens de Montar um Negócio Ambulante.

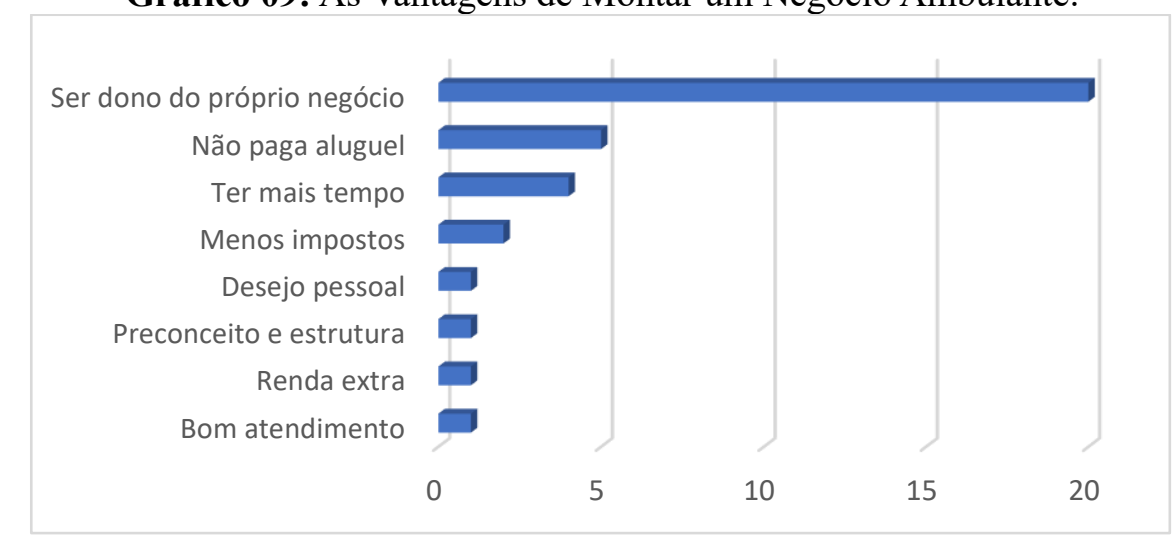

Fonte: Dados da pesquisa 2018

O gráfico 09 evidencia quais as vantagens de empreender de modo ambulante. Dentre essas vantagens pode-se notar que o desejo de ser o dono próprio negócio e não ter chefe é uma das maiores vantagens. Sendo este um motivo que leva as pessoas a empreender. Na sequência a vantagem de não pagar aluguel, com destaque ainda a menos incidência de impostos e ter mais tempo, entendido como espaço livre para realizações pessoais. Desejo pessoal, preconceito e estrutura, renda extra e bom atendimento são outros fatores que levam as pessoas a montar seu próprio negócio, como aponta Oliveira (2014).

Gráfico 10: As Desvantagens de Montar um Negócio Ambulante.

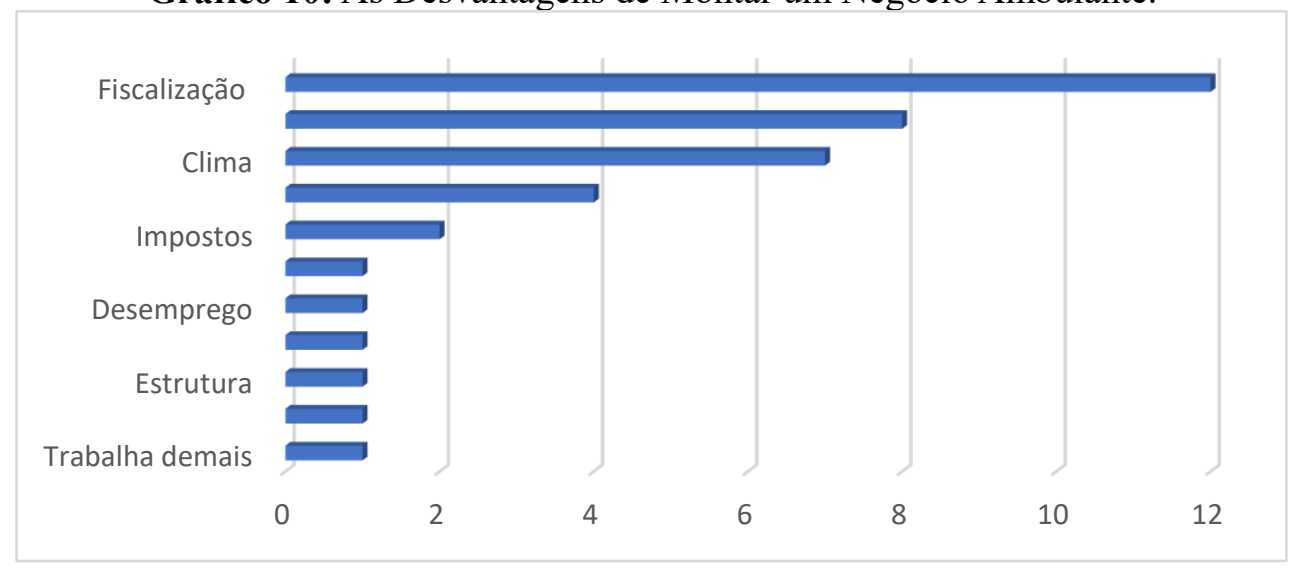

Fonte: Dados da pesquisa 2018.

O gráfico 10 revela as desvantagens percebidas pelos empreendedores a montar um negócio ambulante. Entre estas se destaca a fiscalização, isso se dar devido a grande quantidade de empreendedores que não possui uma formalização e não procuram um órgão de apoio para o desenvolvimento do seu negócio como evidencia o gráfico 05 . 
O clima também foi um fator considerável como desvantagem. O maior destaque se dar pela uma grande parcela dos entrevistados acreditarem que não enxerga nenhuma desvantagem de montar um negócio ambulante. Também são citados como desvantagens elementos de estrutura do negócio, por exemplo, o atendimento, imposto, desemprego, flexibilidade, desperdícios e muito trabalho. Neste paralelo de motivos que levaram a empreender e vantagens de ser ambulante, o gráfico 11 apresenta as vantagens frente aos concorrentes que possuem lojas físicas.

Gráfico 11: Vantagem Frente aos Concorrentes de Lojas Físicas.

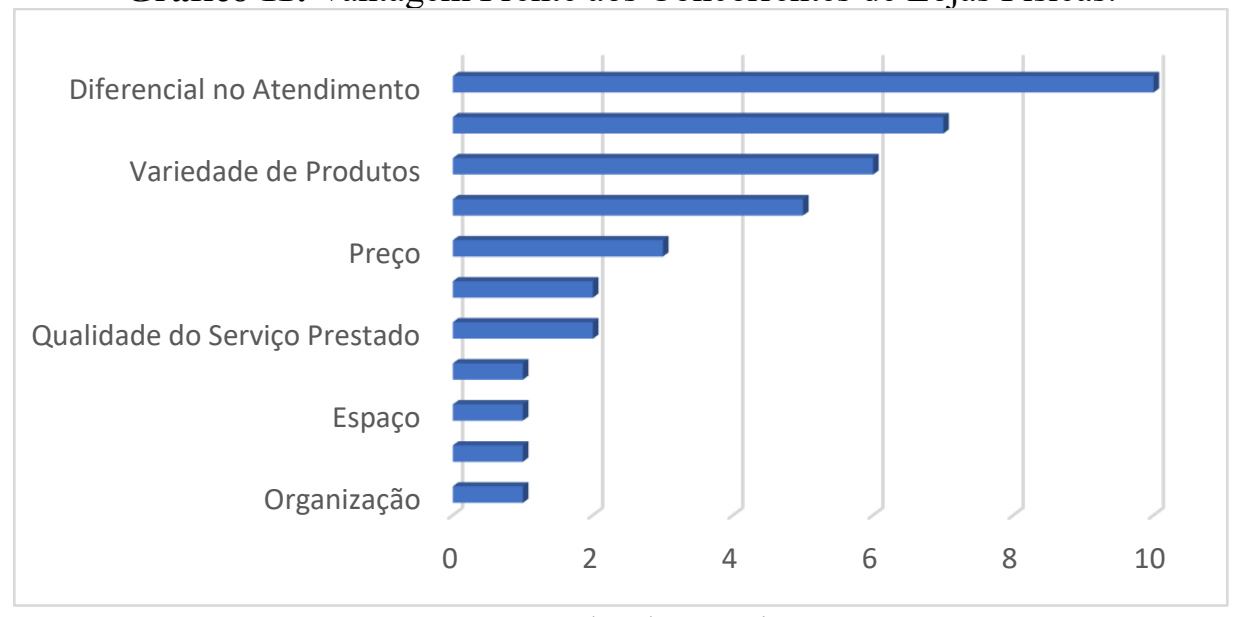

Fonte: Dados da pesquisa 2018.

O gráfico 11 demostra com maior supremacia, que a principal vantagem se encontra em relação ao diferencial no atendimento, pois acreditam que o atendimento é um fator de extrema importância para o desenvolvimento do negócio. Também é pontuada a inexistência de nenhuma vantagem. Mas de maneira curiosa, percebe-se que a variedade e qualidade dos produtos são citadas como uma vantagem, levando a entender que o bem ofertado ao cliente é um diferencial com relação às lojas físicas concorrentes, para alguns.

Ainda sobre o gráfico 11, uma pequena parcela de ambulantes pontua que possuem vantagens ao fornecer satisfação ao cliente, preço bom, higiene, qualidade do serviço e organização. Pode-se dizer então que estes pontos são competências as quais os ambulantes usufruem como vantagens competitivas ditas por Julien (2010). 
Gráfico 12: Vantagens de Empreender em Tempo de Crise Econômica.

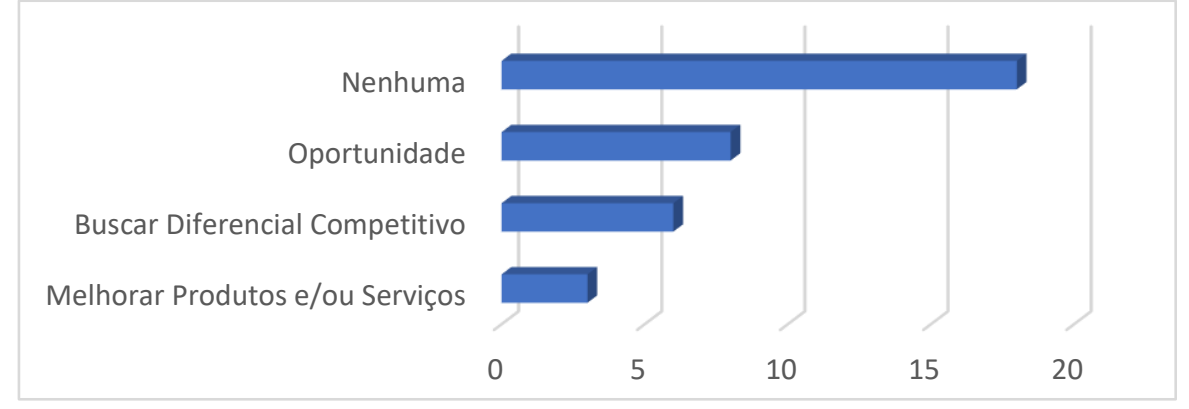

Fonte: Dados da pesquisa 2018.

O gráfico 12 destina-se a apresentar as principais vantagens de empreender em tempo de crise econômica. Uma grande parcela dos empreendedores não ver nenhum tipo de vantagem de empreender em período de crise devido as grandes dificuldades que o país vive principalmente econômica. Já outros empreendedores buscam através da crise novas oportunidades de criar negócios para superar essa fase. O diferencial competitivo e a melhora de produtos e serviços estão entre as principais vantagens citadas entre os entrevistados. No gráfico 13 aponta a influência da crise no negócio ambulante.

Gráfico 13: Influência da Crise no Negócio.

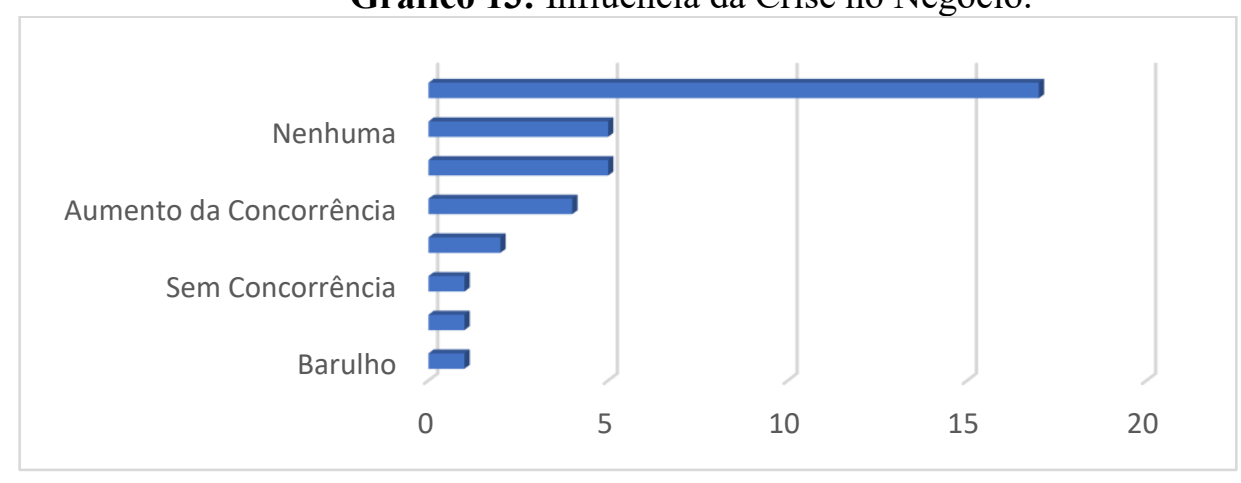

Fonte: Dados da pesquisa 2018

O gráfico 13 mostra quais foram as influencias da crise sobre o ambulante, sendo nítido que a maioria dos entrevistados disse que foi a diminuição dos clientes. Afinal a redução de clientes é um dos principais efeitos da crise como disse Rigon, (2016). Outros falaram que a crise não apresentou nenhuma influência ao negócio, todavia alguns apontaram o aumento do preço dos produtos, certamente da matéria-prima. Também foi colocado em pauta o aumento da concorrência, como a crise gerou desempregos, muitas pessoas buscaram oportunidades de trabalho como ambulantes nas ruas, elevando o grau competitivo. No entanto foi dito que a crise tirou a concorrência, mas analisando que alguns disseram a redução na circulação de dinheiro, significa menos consumidores, fazendo então muitos 
empreendedores ambulantes desistir do empreendimento.

Gráfico 14: Maior Dificuldade Como Ambulante.

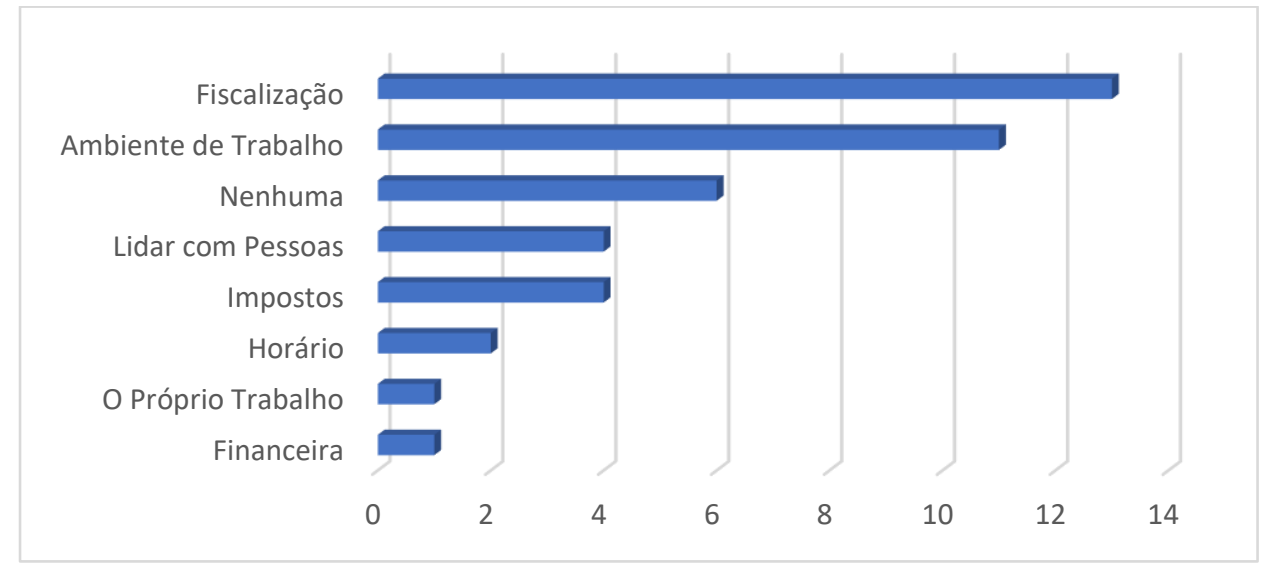

Fonte: Dados da pesquisa 2018.

No gráfico 14 aponta as maiores dificuldades em ser ambulante, a uma predominância na fiscalização como problema enfrentado, visto que a qualquer momento o empreendedor pode ter que fechar o empreendimento por conta da ilegalidade, considerando os gráficos 03 e 08 . É apontado ainda o ambiente de trabalho como uma dificuldade, considerando questões de segurança e estrutura física. Outros discutem que não veem nenhum tipo de dificuldade. $\mathrm{Na}$ sequencia foi dito que lidar com pessoas, impostos, horários, o próprio trabalho e finanças são os problemas enfrentados, podendo afirmar a particularidade de cada um, em está a frete de negócio. No gráfico 15 aponta as formas de como cada empreendedor ambulante aprendeu a profissão que executa.

Gráfico 15: Como Aprendeu a sua Profissão.

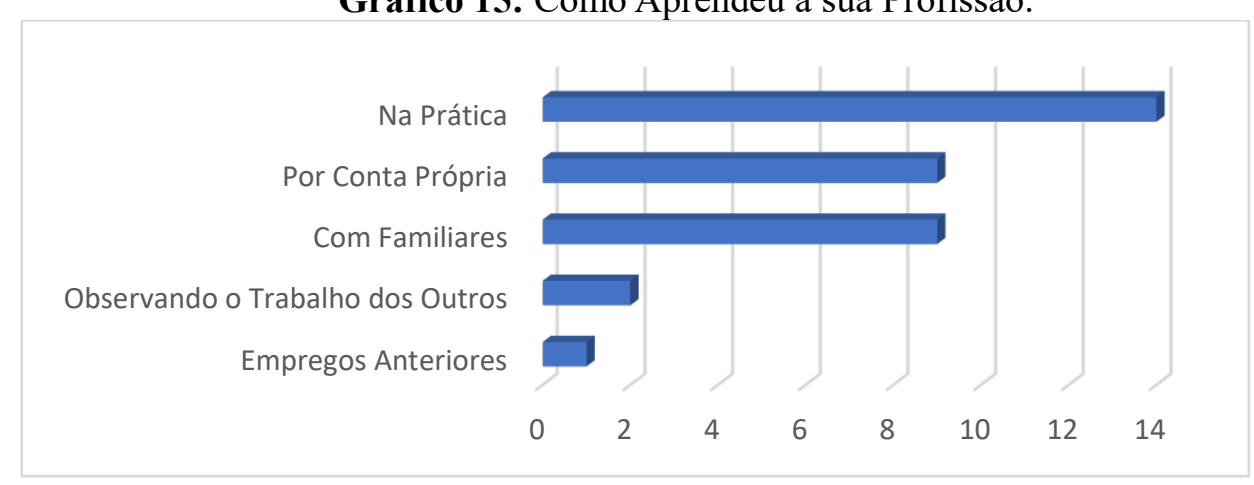

Fonte: Dados da pesquisa 2018. 
Analisando o gráfico 15 percebe-se que a maioria dos empreendedores aprendeu principalmente na prática e por conta própria a manusear e conduzir o negócio. Outros aprenderam dentro de um contexto familiar, passando por uma geração todo um conhecimento. Alguns dos entrevistados apreenderam observando outras pessoas tralhando e em empregos anteriores. Esta analise confirma o que foi mencionado por Robbins (2005) e Hisrich (2014).

\section{Considerações Finais}

Após a abordagem proposta neste artigo, as análises permitiram atingir o objetivo deste artigo, que foi identificar os fatores influenciadores que levam indivíduos a torna-se empreenderes ambulantes no setor alimentício na cidade de Juazeiro do Norte-CE. No primeiro objetivo, a análise descritiva mostrou que o desemprego, melhorar a condição financeira, ser útil para a sociedade e ter mais disponibilidade de tempo são necessidades para abrir um negócio ambulante.

Em relação aos objetivos específicos, estudou as características empreendedoras e analisou os fatores motivacionais que levam ambulantes a empreender como, ser dono do próprio negócio e desejo pessoal.

A problemática foi respondida, visto que o motivo de indivíduos montarem negócios em tempo de crise na cidade de Juazeiro do Norte-CE, está no fato de possuir oportunidades, ter diferencial competitivo e melhorias em produtos existentes.

As hipóteses foram testadas, aonde pode-se notar que o desejo pessoal de reconhecimento ou prestígio é um fator de motivação para empreender. O aumento da taxa de desemprego no país gerou a necessidade de torna-se dono do próprio negócio. Comprovando também a necessidade de melhorar a condição financeira. O desejo de prestar um serviço que realmente seja útil e traga benefícios para a sociedade também é considerado fator de motivação. Ressaltando ainda na liberdade de tempo que os empreendedores ambulantes querem obter.

A pesquisa mostrou ainda que as mulheres detém menor participação no empreendedorismo, no entanto portam maiores níveis de escolaridade. Foi visto também que muitos ambulantes já possuíram mais de um tipo de negócio, mas por falta de planejamento 
ocorreu à falência. Percebeu-se também a informalidade dos profissionais, pois a maioria não possui o CNPJ. Sendo esta a maior dificuldade de trabalho apontada.

O presente estudo limitou-se na compreensão dos motivos que levam as pessoas empreenderem de maneira ambulante no ramo de alimentos. Contudo é perceptível a dificuldade de formalização do negócio, ficando para futuras pesquisas a criação de métodos que forneçam informações a estes empreendedores, acerca da legalidade da ideia, oportunidade ou necessidade de empreender na cidade de Juazeiro do norte-CE.

\section{Referências}

ANDRADE, Maria Margarida de. Introdução à metodologia do trabalho científico: Elaboração de Trabalhos na Graduação. 10. ed. São Paulo: Atlas, 2010.

BAGGIO, Adelar Francisco; BAGGIO, Daniel Knebel. Empreendedorismo: Conceitos e Definições. Rev. de Empreendedorismo, Inovação e Tecnologia, p. 25 - 37, 2014.

GEM, Global Entrepreneurship Monitor. Empreendedorismo no Brasil. 22 ed. Curitiba: IBQP, 2017.

HISRICH, Robert D. Empreendedorismo. 9. ed. Porto Alegre: AMGH, 2014.

IBGE. População e Características Físicas de Juazeiro do Norte - Ceará. Disponível em: <https://cidades.ibge.gov.br/brasil/ce/juazeiro-do-norte/panorama>. Acesso em: 20 abr. 2018.

JULIEN, Pierre André. Empreendedorismo Regional e a Economia do Conhecimento. São Paulo: Saraiva, 2010.

KAUTONEN, T.; PALMROOS, J. The impact of a necessity-based start-up on subsequente entrepreneurial satisfaction. International Entrepreneurship and Management Journal, v. 6, n. 3, p. 285-300, 2010.

LENZI, Fernando César. A Nova Geração de Empreendedores: Guia para Elaboração de um Plano de Negócios. 1 ed. São Paulo: Atlas, 2009.

MARITZ, A. New Zealand necessity entrepreneurs. International Journal of Entrepreneurship and Small Business, v. 1, n. 3-4, p. 255-264, 2004. 
MALHEIROS, Bruno Taranto. Metodologia da Pesquisa em Educação. Rio de Janeiro: LTC, 2011.

MENDES, Jerônimo. Empreendedorismo 360: A Prática na Prática. 3. ed. São Paulo: Atlas, 2017.

OLIVEIRA, Djalma de Pinho Rebouças. Empreendedorismo: Vocação, Capacitação e Atuação Direcionada para o Plano de Negócio. São Paulo: Atlas, 2014.

RIGON, Fernando. O Cenário Atual da Economia Brasileira e as Tendências para as Cooperativas de Crédito: Caso Sicredi. Ijuí: UNIJUÍ, 2016.

TAJRA, Sanmya Feitosa. Empreendedorismo: Conceitos e Práticas Inovadoras. 1. ed. São Paulo: Érica, 2014.

QUEIROZ, Maria Isaura Pereira De. Variações sobre a técnica de gravador no registro da informação viva. São Paulo: T. A., 1991.

Como citar este artigo (Formato ABNT):

AZEVEDO, Italo Juan Fernandes; LEITE, Márcia Maria. Análise dos Fatores Influenciadores do Empreendedorismo Ambulante no Setor Alimentício na Cidade de Juazeiro do Norte-CE. Id on Line Rev.Mult. Psic., 2018, vol.12, n.42, p. 840-857. ISSN: 1981-1179.

Recebido: 20/10/2018;

Aceito: $24 / 10 / 2018$ 